\title{
Association between solar insolation and a history of suicide attempts in bipolar I disorder
}

\section{Bauer, Michael}

2019-06

Bauer, M , Glenn , T, Alda, M, Andreassen, O A, Angelopoulos , E , Ardau, R, Ayhan , Y, Baethge , C , Bauer , R, Baune , B T , Becerra-Palars , C, Bellivier , F, Belmaker , R H , Berk, M, Bersudsky, Y, Bicakci, S, Birabwa-Oketcho, H, Bjella , T D, Cabrera , J , Cheung , E Y W , Del Zompo , M , Dodd , S , Donix , M , Etain , B , Fagiolini , A , Fountoulakis , K N , Frye , M A , Gonzalez-Pinto , A , Gottlieb , J F , Grof , P , Harima , H , Henry , C , Isometsä, E T , Janno , S , Kapczinski , F, Kardell , M , Khaldi , S , Kliwicki , S , Konig , B , Kot , T L , Krogh , R , Kunz , M , Lafer , B , Landen, M , Larsen , E R , Lewitzka , U , Licht , R W , Lopez-Jaramillo , C , MacQueen , G, Manchia , M , Marsh , W , Martinez-Cengotitabengoa, M , Melle , I, Meza-Urzua, F, Ming , M Y, Monteith , S , Morken, G, Mosca, E, Mozzhegorova, A A, Munoz, R, Mythri , S V , Nacef , F, Nadella , R K, Nery , F G , Nielsen, R E , O'Donovan , C , Omrani , A, Osher , Y, Sorensen , H O , Ouali , U , Ruiz , Y P , Pilhatsch , M , Pinna, M , da Ponte , F D R, Quiroz, D , Ramesar , R , Rasgon, N, Reddy, M S, Reif, A, Ritter , P, Rybakowski, J K, Sagduyu, K, Raghuraman, B S, Scippa, A M , Severus, E, Simhandl , C, Stackhouse , P W , Stein , D J, Strejilevich, S, Subramaniam, M , Sulaiman, A H, Suominen, K, Tagata, H , Tatebayashi, Y, Tondo , L, Torrent, C, Vaaler, A E, Vares, E, Veeh, J , Vieta , E, Viswanath , B , Yoldi-Negrete , M , Zetina , M , Zgueb , Y \& Whybrow , P C 2019 , ' Association between solar insolation and a history of suicide attempts in bipolar I disorder ' , Journal of Psychiatric Research, vol. 113 , pp. 1-9 . https://doi.org/10.1016/j.jpsychires.2019.03.001

http://hdl.handle.net/10138/317089

https://doi.org/10.1016/j.jpsychires.2019.03.001

publishedVersion

Downloaded from Helda, University of Helsinki institutional repository.

This is an electronic reprint of the original article.

This reprint may differ from the original in pagination and typographic detail.

Please cite the original version. 


\section{Association between solar insolation and a history of suicide attempts in bipolar I disorder}

Michael Bauer ${ }^{\mathrm{a}, *}$, Tasha Glenn $^{\mathrm{b}}$, Martin $\mathrm{Alda}^{\mathrm{c}}$, Ole A. Andreassen ${ }^{\mathrm{d}}$, Elias Angelopoulos ${ }^{\mathrm{e}}$, Raffaella Ardau $^{\mathrm{f}}$, Yavuz Ayhan ${ }^{\mathrm{g}}$, Christopher Baethge ${ }^{\mathrm{h}}$, Rita Bauer ${ }^{\mathrm{a}}$, Bernhard T. Baune ${ }^{\mathrm{i}}$, Claudia Becerra-Palars ${ }^{\mathrm{j}}$, Frank Bellivier ${ }^{\mathrm{k}}$, Robert H. Belmaker ${ }^{1}$, Michael Berk ${ }^{\mathrm{m}, \mathrm{n}}$, Yuly Bersudsky ${ }^{1}$, Şule Bicakci ${ }^{\mathrm{O}}$, Harriet Birabwa-Oketcho ${ }^{\mathrm{p}}$, Thomas D. Bjella ${ }^{\mathrm{d}}$, Jorge Cabrera ${ }^{\mathrm{q}}$, Eric Y. Wo Cheung ${ }^{\mathrm{r}}$, Maria Del Zompo ${ }^{\mathrm{f}}$, Seetal Dodd ${ }^{\mathrm{m}, \mathrm{s}}$, Markus Donix ${ }^{\mathrm{a}}$, Bruno Etain ${ }^{\mathrm{k}}$, Andrea Fagiolini ${ }^{\mathrm{t}}$, Kostas N. Fountoulakis ${ }^{\mathrm{u}}$, Mark A. Frye ${ }^{\mathrm{v}}$, Ana Gonzalez-Pinto ${ }^{\mathrm{w}}$, John F. Gottlieb ${ }^{\mathrm{x}}$, Paul Grof ${ }^{\mathrm{y}}$, Hirohiko Harima $^{z}$, Chantal Henry ${ }^{\text {aa }}$, Erkki T. Isometsä ${ }^{\text {ab,ac }}$, Sven Janno ${ }^{\text {ad }}$, Flávio Kapczinski ${ }^{\text {ae }}$, Mathias Kardell $^{\text {af }}$, Slim Khaldi ${ }^{\text {ag,1 }}$, Sebastian Kliwicki ${ }^{\text {ah }}$, Barbara König ${ }^{\text {ai }}$, Timur L. Kot ${ }^{\text {aj }}$, Rikke Krogh $^{\text {ak }}$, Mauricio Kunz ${ }^{\text {ae }}$, Beny Lafer ${ }^{\text {al }}$, Mikael Landén ${ }^{\text {am,an }}$, Erik R. Larsen ${ }^{\text {ak }}$, Ute Lewitzka $^{\text {a }}$, Rasmus W. Licht ${ }^{\text {ao,ap }}$, Carlos Lopez-Jaramillo ${ }^{\text {aq }}$, Glenda MacQueen ${ }^{\text {ar }}$, Mirko Manchia $^{\text {as,at }}$, Wendy Marsh ${ }^{\text {au }}$, Mónica Martinez-Cengotitabengoa ${ }^{\mathrm{w}}$, Ingrid Melle ${ }^{\mathrm{d}}$, Fátima Meza-Urzúa ${ }^{j}$, Mok Yee Ming ${ }^{\text {av }}$, Scott Monteith ${ }^{\text {aw }}$, Gunnar Morken ${ }^{\text {ax,ay }}$, Enrica Mosca ${ }^{\mathrm{f}}$, Anton A. Mozzhegorov ${ }^{\text {az }}$, Rodrigo Munoz ${ }^{\text {aaa }}$, Starlin V. Mythri ${ }^{\text {aab }}$, Fethi Nacef ${ }^{\text {aac }}$, Ravi K. Nadella ${ }^{\text {aad }}$, Fabiano G. Nery ${ }^{\text {al }}$, René E. Nielsen ${ }^{\text {ao,ap }}$, Claire O'Donovan ${ }^{\mathrm{c}}$, Adel Omrani ${ }^{\text {aae }}$, Yamima Osher ${ }^{1}$, Helle Østermark Sørensen ${ }^{\text {ao }}$, Uta Ouali ${ }^{\text {aac }}$, Yolanda Pica Ruiz ${ }^{\text {aaf }}$, Maximilian Pilhatsch ${ }^{\text {a }}$, Marco Pinna ${ }^{\text {aag }}$, Francisco D.R. da Ponte ${ }^{\text {ae }}$, Danilo Quiroz $^{\text {aah }}$, Raj Ramesar $^{\text {aai }}$, Natalie Rasgon ${ }^{\text {aaj }}$, M.S. Reddy ${ }^{\text {aab }}$, Andreas Reif ${ }^{\text {aak}}$, Philipp Ritter ${ }^{\text {, }}$ Janusz K. Rybakowski ${ }^{\text {ah }}$, Kemal Sagduyu ${ }^{\text {aal }}$, Bharathram Sathur Raghuraman ${ }^{\text {aad }}$, Ângela M. Scippaam, Emanuel Severus ${ }^{\text {a }}$, Christian Simhandl ${ }^{\text {ai }}$, Paul W. Stackhouse Jr. ${ }^{\text {aan }}$, Dan J. Stein ${ }^{\text {aao }}$, Sergio Strejilevich ${ }^{\text {aap }}$, Mythily Subramaniam ${ }^{\text {aaq }}$, Ahmad Hatim Sulaiman ${ }^{\text {aar }}$, Kirsi Suominen $^{\text {aas }}$, Hiromi Tagata ${ }^{z}$, Yoshitaka Tatebayashi ${ }^{\text {aat }}$, Leonardo Tondo ${ }^{\text {aau,aav }}$, Carla Torrent $^{\text {aaw }}$, Arne E. Vaaler ${ }^{\text {ax,ay }}$, Edgar Vares ${ }^{\text {a }}$, Julia Veeh ${ }^{\text {aak }}$, Eduard Vieta ${ }^{\text {aaw }}$, Biju Viswanath ${ }^{\text {aad }}$, Maria Yoldi-Negrete ${ }^{\text {aax }}$, Mark Zetin ${ }^{\text {aay,2}}$, Yosra Zgueb ${ }^{\text {aac }}$, Peter C. Whybrow ${ }^{\text {aaz }}$

\footnotetext{
${ }^{a}$ Department of Psychiatry and Psychotherapy, University Hospital Carl Gustav Carus, Technische Universität Dresden, Dresden, Germany

${ }^{\mathrm{b}}$ ChronoRecord Association, Fullerton, CA, USA

${ }^{\mathrm{c}}$ Department of Psychiatry, Dalhousie University, Halifax, NS, Canada

${ }^{\mathrm{d}}$ NORMENT - K.G. Jebsen Centre for Psychosis Research, Division of Mental Health and Addiction, Oslo University Hospital \& Institute of Clinical Medicine, University of Oslo, Oslo, Norway

e Department of Psychiatry, National and Capodistrian University of Athens, Medical School, Eginition Hospital, Athens, Greece

${ }^{\mathrm{f}}$ Section of Neurosciences and Clinical Pharmacology, Department of Biomedical Sciences, University of Cagliari, Sardinia, Italy

${ }^{\mathrm{g}}$ Department of Psychiatry, Hacettepe University Faculty of Medicine, Ankara, Turkey

${ }^{\mathrm{h}}$ Department of Psychiatry and Psychotherapy, University of Cologne Medical School, Cologne, Germany

${ }^{\mathrm{i}}$ Department of Psychiatry, School of Medicine, University of Adelaide, Adelaide, Australia

${ }^{\mathrm{j}}$ National Institute of Psychiatry "Ramón de la Fuente Muñiz", Mexico City, Mexico

${ }^{\mathrm{k}}$ Psychiatry and Addiction Medicine. Assistance Publique - Hôpitaux de Paris, INSERM UMR-S1144, Denis Diderot University, René Descartes University, FondaMental Foundation, Paris, France

${ }^{1}$ Department of Psychiatry, Faculty of Health Sciences, Beer Sheva Mental Health Center, Ben Gurion University of the Negev, Beer Sheva, Israel
}

\footnotetext{
* Corresponding author. Department of Psychiatry and Psychotherapy, University Hospital Carl Gustav Carus, Technische Universität Dresden, Fetscherstr. 74, 01307, Dresden, Germany.

E-mail address: michael.bauer@uniklinikum-dresden.de (M. Bauer).
} 
${ }^{\mathrm{m}}$ Deakin University, IMPACT Strategic Research Centre, School of Medicine, Barwon Health, Geelong, Victoria, Australia

${ }^{\mathrm{n}}$ Department of Psychiatry, Orygen, the National Centre for Excellence in Youth Mental Health, the Centre for Youth Mental Health and the Florey Institute for

Neuroscience and Mental Health, University of Melbourne, Parkville, Victoria, Australia

${ }^{\circ}$ Van Research and Training Hospital, Van, Turkey

${ }^{\mathrm{p}}$ Butabika Hospital, Kampala, Uganda

${ }^{\mathrm{q}}$ Mood Disorders Clinic, Dr. Jose Horwitz Psychiatric Institute, Santiago de Chile, Chile

${ }^{\mathrm{r}}$ Department of General Adult Psychiatry, Castle Peak Hospital, Hong Kong

${ }^{s}$ Department of Psychiatry, University of Melbourne, Parkville, Victoria, Australia

${ }^{\mathrm{t}}$ Department of Molecular Medicine and Department of Mental Health (DAI), University of Siena and University of Siena Medical Center (AOUS), Siena, Italy

" Division of Neurosciences, 3rd Department of Psychiatry, School of Medicine, Aristotle University of Thessaloniki, Thessaloniki, Greece

${ }^{v}$ Department of Psychiatry \& Psychology, Mayo Clinic Depression Center, Mayo Clinic, Rochester, MN, USA

${ }^{\mathrm{w}}$ Department of Psychiatry, University Hospital of Alava, University of the Basque Country, CIBERSAM, Vitoria, Spain

${ }^{\mathrm{x}}$ Department of Psychiatry, Feinberg School of Medicine, Northwestern University, Chicago, IL, USA

${ }^{\mathrm{y}}$ Mood Disorders Center of Ottawa, University of Toronto, Toronto, ON, Canada

${ }^{\mathrm{z}}$ Department of Psychiatry, Tokyo Metropolitan Matsuzawa Hospital, Setagaya, Tokyo, Japan

${ }^{\text {aa }}$ AP-HP, Hopitaux Universitaires Henri Mondor and INSERM U955 (IMRB) and Université Paris Est and Institut Pasteur, Unité Perception et Mémoire, Paris, France

${ }^{\mathrm{ab}}$ Department of Psychiatry, University of Helsinki and Helsinki University Hospital, Helsinki, Finland

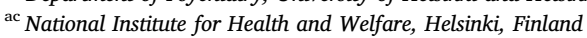

${ }^{\text {ad }}$ Department of Psychiatry, University of Tartu, Tartu, Estonia

ae Department of Psychiatry, Universidade Federal do Rio Grande do Sul, Porto Alegre, Brazil

${ }^{\text {af }}$ Department of Psychiatry and Neurochemistry, Institute of Neuroscience and Physiology, The Sahlgrenska Academy, University of Gothenburg, Gothenburg, Sweden

${ }^{\text {ag }}$ Private practice, Tunis, Tunisia

${ }^{\text {ah }}$ Department of Adult Psychiatry, Poznan University of Medical Sciences, Poznan, Poland

ai BIPOLAR Zentrum Wiener Neustadt, Wiener Neustadt, Austria

${ }^{\text {aj }}$ Khanty-Mansiysk Clinical Psychoneurological Hospital, Khanty-Mansiysk, Russia

${ }^{\mathrm{ak}}$ Department of Affective Disorders, Q, Mood Disorders Research Unit, Aarhus University Hospital, Aarhus, Denmark

${ }^{\text {al }}$ Bipolar Disorder Research Program, Department of Psychiatry, University of São Paulo Medical School, São Paulo, Brazil

${ }^{a m}$ Department of Psychiatry and Neurochemistry, Institute of Neuroscience and Physiology, the Sahlgrenska Academy, University of Gothenburg, Gothenburg and Mölndal, Sweden

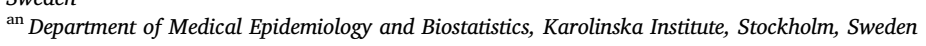

${ }^{\text {ao }}$ Unit for Psychiatric Research, Aalborg University Hospital, Psychiatry, Aalborg, Denmark

${ }^{\text {ap }}$ Department of Clinical Medicine, Aalborg University, Aalborg, Denmark

${ }^{a \mathrm{a}}$ Mood Disorders Program, Hospital Universitario San Vicente Fundación, Research Group in Psychiatry, Department of Psychiatry, Faculty of Medicine, Universidad de Antioquia, Medellín, Colombia

${ }^{\text {ar }}$ Department of Psychiatry, Faculty of Medicine, University of Calgary, Calgary, AB, Canada

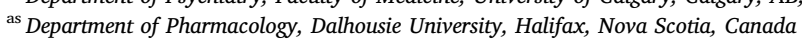

${ }^{\text {at }}$ Section of Psychiatry, Department of Medical Science and Public Health, University of Cagliari, Cagliari, Italy

${ }^{\text {au }}$ Department of Psychiatry, University of Massachusetts, Worcester, MA, USA

${ }^{a v}$ Department of General Psychiatry, Mood Disorders Unit, Institute of Mental Health, Singapore City, Singapore

${ }^{\text {aw }}$ Michigan State University College of Human Medicine, Traverse City Campus, Traverse City, MI, USA

${ }^{a x}$ Department of Mental Health, Norwegian University of Science and Technology - NTNU, Trondheim, Norway

ay Department of Psychiatry, St Olavs' University Hospital, Trondheim, Norway

${ }^{\text {az }}$ Soviet Psychoneurological Hospital, Urai, Russia

aaa Department of Psychiatry, University of California San Diego, San Diego, CA, USA

${ }^{\mathrm{aab}}$ Asha Bipolar Clinic, Asha Hospital, Hyderabad, Telangana, India

${ }^{\text {acc }}$ Razi Hospital, Faculty of Medicine, University of Tunis-El Manar, Tunis, Tunisia

aad Department of Psychiatry, NIMHANS, Bangalore, India

aae Tunisian Bipolar Forum, Érable Médical Cabinet 324, Lac 2, Tunis, Tunisia

${ }^{\text {aaf }}$ Hospital "Ángeles del Pedregal", Mexico City, Mexico

${ }^{\text {aag }}$ Lucio Bini Mood Disorder Center, Cagliari, Italy

ah Deparment of Psychiatry, Diego Portales University, Santiago de Chile, Chile

${ }^{\text {aai }}$ UCT/MRC Human Genetics Research Unit, Division of Human Genetics, Institute of Infectious Disease and Molecular Medicine, University of Cape Town, Cape Town, South Africa

${ }^{\text {aaj }}$ Department of Psychiatry and Behavioral Sciences, Stanford School of Medicine, Palo Alto, CA, USA

${ }^{\text {aak }}$ Department of Psychiatry, Psychosomatic Medicine and Psychotherapy, University Hospital Frankfurt, Johann Wolfgang Goethe-Universität Frankfurt am Main,

Frankfurt am Main, Germany

${ }^{\text {aal }}$ Department of Psychiatry, University of Missouri Kansas City School of Medicine, Kansas City, MO, USA

${ }^{\text {aam }}$ Department of Neuroscience and Mental Health, Federal University of Bahia, Salvador, Brazil

${ }^{\text {aan }}$ Science Directorate/Climate Science Branch, NASA Langley Research Center, Hampton, VA, USA

${ }^{\text {aao }}$ Department of Psychiatry, MRC Unit on Risk \& Resilience in Mental Disorders, University of Cape Town, Cape Town, South Africa

${ }^{\text {aap }}$ Bipolar Disorder Program, Neuroscience Institute, Favaloro University, Buenos Aires, Argentina

${ }^{\text {aaq }}$ Research Division, Institute of Mental Health, Singapore

${ }^{a a r}$ Department of Psychological Medicine, Faculty of Medicine, University of Malaya, Kuala Lumpur, Malaysia

${ }^{\text {aas }}$ Department of Social Services and Health Care, Psychiatry, City of Helsinki, Finland

${ }^{\text {aat }}$ Schizophrenia \& Affective Disorders Research Project, Tokyo Metropolitan Institute of Medical Science, Seatagaya, Tokyo, Japan

${ }^{\text {aau }}$ McLean Hospital-Harvard Medical School, Boston, MA, USA

${ }^{\text {aav }}$ Mood Disorder Lucio Bini Centers, Cagliari e Roma, Italy

${ }^{\text {aaw }}$ Clinical Institute of Neuroscience, Hospital Clinic, University of Barcelona, IDIBAPS, CIBERSAM, Barcelona, Catalonia, Spain

${ }^{\text {aax }}$ Consejo Nacional de Ciencia y Tecnología - Instituto Nacional de Psiquiatría Ramón de la Fuente Muñiz, Ciudad de México, Mexico

aay Department of Psychology, Chapman University, Orange, CA, USA

${ }^{\mathrm{aaz}}$ Department of Psychiatry and Biobehavioral Sciences, Semel Institute for Neuroscience and Human Behavior, University of California Los Angeles (UCLA), Los Angeles, CA, USA 


\section{Keywords:}

Bipolar disorder

Suicide

Sunlight

Solar insolation

Seasonal variation

\begin{abstract}
A B S T R A C T
In many international studies, rates of completed suicide and suicide attempts have a seasonal pattern that peaks in spring or summer. This exploratory study investigated the association between solar insolation and a history of suicide attempt in patients with bipolar I disorder. Solar insolation is the amount of electromagnetic energy from the Sun striking a surface area on Earth. Data were collected previously from 5536 patients with bipolar I disorder at 50 collection sites in 32 countries at a wide range of latitudes in both hemispheres. Suicide related data were available for 3365 patients from 310 onset locations in 51 countries. 1047 (31.1\%) had a history of suicide attempt. There was a significant inverse association between a history of suicide attempt and the ratio of mean winter solar insolation/mean summer solar insolation. This ratio is smallest near the poles where the winter insolation is very small compared to the summer insolation. This ratio is largest near the equator where there is relatively little variation in the insolation over the year. Other variables in the model that were positively associated with suicide attempt were being female, a history of alcohol or substance abuse, and being in a younger birth cohort. Living in a country with a state-sponsored religion decreased the association. (All estimated coefficients $\mathrm{p}<0.01)$. In summary, living in locations with large changes in solar insolation between winter and summer may be associated with increased suicide attempts in patients with bipolar disorder. Further investigation of the impacts of solar insolation on the course of bipolar disorder is needed.
\end{abstract}

\section{Introduction}

Patients with bipolar disorder have a very high risk of suicidal behavior with about $1 / 3$ of patients attempting suicide at least once (Novick et al., 2010; Tondo et al., 2016). A complex interplay of diverse factors contribute to suicidal behavior, including cultural, socioeconomic, genetic, stressful life experiences, the course of bipolar disorder and physical health (Schaffer et al., 2015; Tondo et al., 2016). Research has also found a relation between environmental factors and suicide rates. Many international studies of the general population have reported a seasonal variation in completed suicide and suicide attempts with peak rates in spring or summer (Barker et al., 1994; Christodoulou et al., 2012; Coimbra et al., 2016; Dixon and Kalkstein, 2018; Woo et al., 2012; Galvão et al., 2018; Odagiri et al., 2011; Petridou et al., 2002). Seasonality in suicide may be associated with a prior psychiatric diagnosis (Postolache et al., 2010; Reutfors et al., 2009; Rocchi et al., 2007).

This association of suicide rates with environmental factors is of considerable concern since circadian rhythm disturbances are found in many psychiatric illnesses, including bipolar disorder (Carr et al., 2018; Jagannath et al., 2013; Jones and Benca, 2015; Logan and McClung, 2019). Although strongly linked, the relationship between circadian disruption and the development and course of bipolar disorder is complex, bidirectional and not understood (Bechtel, 2015; Harvey, 2008; Ketchesin et al., 2018; Logan and McClung, 2019; McCarthy, 2018; McCarthy and Welsh, 2012; Oliveira et al., 2018). Circadian disturbances that occur frequently in bipolar disorder include alterations to the sleep/wake cycle and daily hormonal secretion, and misalignments between external time and social activities (Abreu and Bragança, 2015; Bellivier et al., 2015; Talih et al., 2018; Wirz-Justice, 2006). While symptoms of circadian disruption are most prominent during episodes of mania or depression, many occur when patients are euthymic including sleep disturbances, irregular social rhythms, preference for evening activities, and abnormalities in melatonin secretion (Alloy et al., 2017; Melo et al., 2017; Ng et al., 2015; Soreca, 2014; Takaesu, 2018). About one-fourth of patients with bipolar disorder experience a seasonal pattern in episode type, with manic episodes peaking in spring/summer and depression in winter (Geoffroy et al., 2014, 2015). Hospitalizations for mania are more numerous in spring/ summer than in winter (Aguglia et al., 2017; Geoffroy et al., 2014). Some treatments for bipolar disorder may directly or indirectly target

\footnotetext{
${ }^{1}$ Died in 2016.

${ }^{2}$ Died in 2017
}

the circadian system (Bellivier et al., 2015; McClung, 2007).

Analyzing a large global sample, we previously found a strong, inverse relation between the maximum monthly increase in solar insolation in springtime and the age of onset of bipolar I disorder (Bauer et al., 2012, 2014; 2017), where solar insolation is defined as the amount of electromagnetic energy from the Sun striking a surface area of the Earth, expressed in kilowatt hours/square meter/day $\left(\mathrm{kWh} / \mathrm{m}^{2}\right.$ / day) (Stackhouse et al., 2018).

This replicated finding suggests that some patients with bipolar disorder may have difficulty adjusting to an environmental challenge to the circadian system. The purpose of this exploratory post-hoc analysis was to investigate if solar insolation was associated with a history of suicide attempts in patients with bipolar I disorder, using the data previously collected.

\section{Methods}

\subsection{Data collection}

Data were collected between 2010 and 2016 by researchers at 50 sites in 32 countries to study the effects of solar insolation on the age of onset of bipolar disorder (Bauer et al., 2017). The database contains information on 7392 patients of which 5536 patients have a diagnosis of bipolar I disorder based on DSM-IV criteria. Data were obtained by patient questioning, record review or both. Study approval, including for data collection, was obtained according to local requirements, using local institutional review boards. To maximize global participation, the database only includes minimal clinical data. Three locations were collected for every patient: birth location, onset location of bipolar disorder, and current location. Details about the project methodology were published previously (Bauer et al., 2012, 2014; 2017).

The 50 collection sites are in both the northern and southern hemispheres: Aalborg, Denmark; Aarhus, Denmark; Adelaide, Australia; Ankara, Turkey; Athens, Greece; Bangalore, India; Barcelona, Spain; Beer Sheva, Israel; Buenos Aires, Argentina; Cagliari, Sardinia, Italy (2 sites); Calgary, Canada; Cape Town, South Africa; Dresden, Germany; Halifax, Canada; Helsinki, Finland; Hong Kong; Hyderabad, India; Kampala, Uganda; Kansas City, KS, USA; Khanti-Mansiysk, Russia; Kuala Lumpur, Malaysia; Los Angeles, CA, USA; Medellín, Colombia; Melbourne/Geelong, Australia; Mexico City, Mexico; Oslo, Norway; Ottawa, Canada; Palo Alto, CA, USA; Paris, France; Porto Alegre, Brazil; Poznan, Poland; Rochester, MN, USA; San Diego, CA, USA; Santiago, Chile (2 sites); Salvador, Brazil; São Paulo, Brazil; Siena, Italy; Singapore; Stockholm/Gothenburg, Sweden; Tartu, Estonia; 
Thessaloniki, Greece; Tokyo, Japan; Trondheim, Norway; Tunis, Tunisia; Vitoria, Spain; Wiener Neustadt, Austria; Worcester, MA, USA, and Würzburg, Germany.

\subsection{Solar insolation}

The NASA POWER database provides global $35+$ year average monthly solar insolation data based on satellite observations collected between 1983 and the present (Stackhouse et al., 2018). This study uses a 22-year climatology of solar insolation spanning 1983 to 2005 at a spatial resolution of $1^{\circ} \times 1^{\circ}$ latitude/longitude. The pattern of monthly solar insolation varies by latitude during the course of a year, with little change at the equator and the greatest change near the north and south poles. Local conditions including cloud cover, aerosols (including dust and pollution), water vapor amounts, and altitude result in very different solar insolation for locations at the same latitude. For example, Nice, France at latitude $43.70 \mathrm{~N}$, and Toronto, Canada at latitude $43.67 \mathrm{~N}$ have the same hours of daylight but receive different solar insolation due to local conditions.

For every location, monthly and seasonal variables were created using the monthly solar insolation averages. The ratio of the mean northern hemisphere winter (December, January, February) to mean summer (June, July, August) insolation was calculated as mean winter insolation/mean summer insolation. The insolation data from the southern hemisphere were shifted by 6 months for comparison to data from the northern hemisphere to account for the seasonal cycle.

\subsection{Country data}

A variety of socioeconomic variables were investigated including the physician density of any specialty per 1000 population, psychiatrists per 100,000, GDP per capita, total healthcare spending as a percent of GDP, the Gini index of income inequality, and the country median age (CIA World Factbook, 2016; WHO, 2005). Data were also obtained on whether the country has a state-sponsored or officially favored religion (Pew Research, 2017).

\subsection{Statistics}

The generalized estimating equations (GEE) statistical technique was selected to account for both the correlated data and unbalanced number of patients at the international collection sites. The GEE uses a population averaged or marginal approach, estimating the dependent variable as a function of the covariates across the entire population rather than within a cluster (Zeger and Liang, 1986). The GEE models were estimated using a binomial distribution, exchangeable working correlation matrix and a logit link function. In all models, a history of suicide attempts was the dependent variable. Several approaches were used to select the variables and the best model. The potential variables from univariate analyses that were significant at a level of 0.05 , and variables found in prior suicide research were entered into multivariate models. The corrected quasi-likelihood independence model criterion was used to assist with multivariate model fitting (Pan, 2001). The odds ratios and confidence intervals generated by the GEE are reported. A significance level of 0.01 was used for multivariate model evaluation to reduce the chance of type I errors. Demographic variables were reported using descriptive statistics. SPSS version 24.0 was used for all analyses.

\section{Results}

\subsection{Patient demographics and locations}

There were 5536 patients with a diagnosis of bipolar I disorder in the database, of which a history of suicide was available for 3897 patients. However, only 3365 patients were included in the analysis after eliminating those who did not have all five variables in the final model. All 532 patients eliminated for not having the five variables were missing only one variable. Of the 532 patients, all but 2 were missing a history of alcohol or substance abuse data. Of the 3365 patients in the final model, 1908 (56.7\%) were female, 1457 (43.3\%) were male, and $1047(31.1 \%)$ had a history of suicide attempt. The demographic characteristics of the 3365 patients are shown in Table 1. The birth cohort groups from our prior analyses were used, with $4.8 \%$ born before 1940, 29.1\% born between 1940 and 1959, and 66.1\% born 1960 or later (Bauer et al., 2012, 2014; 2015, 2017).

The onset location was used in all analyses. Of the 3365 patients, the onset location country and current country was the same for 3286 (97.7\%), and the onset location city and current city was the same for $2746(81.6 \%)$. For the 3365 patients, the onset of bipolar disorder occurred in 310 locations in 51 countries. The larger number of onset locations than collection sites is consistent with worldwide migration into urban areas (WHO, 2018). The onset locations represent a wide range of latitudes in the northern and southern hemispheres as shown in Table 2. Each location contained a mean of 11 patients, with $5.3 \%$ of the 3365 patients in a location of one.

\subsection{Ratio of mean winter solar insolation/mean summer solar insolation}

In locations that are near the poles, the mean solar insolation in winter is very small when compared to the summer solar insolation, resulting in a very small ratio. For example, the ratio was 0.067 for Trondheim, Norway and 0.095 for Khanti-Mansiysk, Russia. In contrast, locations near the equator have little change in winter and summer insolation and a ratio near 1, such as 1.140 for Kampala, Uganda and 1.056 for Singapore. See Table 2. Log transformation of the ratio was not required.

\subsection{Model results}

The best fitting model for a history of suicide attempts is shown in Table 3. This model includes the ratio of mean winter solar insolation/ mean summer solar insolation, gender, history of alcohol or substance

Table 1

Demographics of bipolar I patients $(\mathrm{N}=3365)$.

\begin{tabular}{|c|c|c|c|}
\hline Parameter & Value & $\mathrm{N}$ & $\%$ \\
\hline \multicolumn{4}{|l|}{ Gender } \\
\hline & Female & 1908 & 56.7 \\
\hline & Male & 1457 & 43.3 \\
\hline \multicolumn{4}{|l|}{ First Episode ${ }^{a}$} \\
\hline & Manic/Hypomanic & 1575 & 49.1 \\
\hline & Depressed & 1634 & 50.9 \\
\hline \multicolumn{4}{|c|}{ Family History of Mood Disorder ${ }^{a}$} \\
\hline & No & 1374 & 44.0 \\
\hline & Yes & 1748 & 56.0 \\
\hline \multicolumn{4}{|c|}{ Alcohol or Substance Abuse } \\
\hline & No & 2208 & 65.6 \\
\hline & Yes & 1157 & 34.4 \\
\hline \multicolumn{4}{|c|}{ State-Sponsored Religion in Country of Onset } \\
\hline & No & 1796 & 53.4 \\
\hline & Yes & 1569 & 46.6 \\
\hline \multicolumn{4}{|c|}{ History of Suicide Attempts } \\
\hline & No & 2318 & 68.9 \\
\hline & Yes & 1047 & 31.1 \\
\hline \multicolumn{4}{|l|}{ Cohort Group } \\
\hline & DOB $<1940$ & 162 & 4.8 \\
\hline & $\mathrm{DOB} \geq 1940$ and $<1960$ & 978 & 29.1 \\
\hline & DOB $\geq 1960$ & 2225 & 66.1 \\
\hline \multicolumn{2}{|l|}{ Parameter } & Mean & SD \\
\hline \multicolumn{2}{|l|}{ Age } & 50.5 & 15.01 \\
\hline \multicolumn{2}{|l|}{ Age of Onset } & 25.7 & 10.71 \\
\hline
\end{tabular}

${ }^{\mathrm{a}}$ Missing values excluded. 
Table 2

Distribution of latitudes for patient onset locations $(\mathrm{N}=3365)$.

\begin{tabular}{|c|c|c|c|c|}
\hline $\begin{array}{l}\text { Degrees Latitude } \\
\text { North + South }\end{array}$ & $\mathrm{N}$ & $\%$ & $\begin{array}{l}\text { Ratio Mean Winter } \\
\text { Insolation/Mean } \\
\text { Summer Insolation }\end{array}$ & Example Locations \\
\hline $0-9$ & 219 & 6.5 & 1.0283 & $\begin{array}{l}\text { Kampala, Uganda } \\
\text { Medellín, Columbia } \\
\text { Singapore }\end{array}$ \\
\hline $10-19$ & 212 & 6.3 & 1.0686 & $\begin{array}{l}\text { Bangalore, India } \\
\text { Hyderabad, India } \\
\text { Mexico City, Mexico }\end{array}$ \\
\hline $20-29$ & 215 & 6.4 & 0.7238 & $\begin{array}{l}\text { Cancun, Mexico } \\
\text { Hong Kong, China } \\
\text { São Paulo, Brazil }\end{array}$ \\
\hline $30-39$ & 965 & 28.7 & 0.3843 & $\begin{array}{l}\text { Adelaide, Australia } \\
\text { Athens, Greece } \\
\text { Beersheva, Isreal } \\
\text { Cagliari, Italy } \\
\text { Cape Town, South } \\
\text { Africa } \\
\text { Los Angeles, CA, } \\
\text { USA } \\
\text { Santiago, Chile } \\
\text { Tokyo, Japan } \\
\text { Tunis, Tunisia }\end{array}$ \\
\hline $40-49$ & 1153 & 34.3 & 0.2939 & $\begin{array}{l}\text { Barcelona, Spain } \\
\text { Boston, MA, USA } \\
\text { Nova Scotia, } \\
\text { Canada } \\
\text { Paris, France } \\
\text { Siena, Italy } \\
\text { Vienna, Austria } \\
\text { Würzburg, Germany }\end{array}$ \\
\hline $50-59$ & 365 & 10.8 & 0.1453 & $\begin{array}{l}\text { Aarhus, Denmark } \\
\text { Poznan, Poland } \\
\text { Stockholm, Sweden } \\
\text { Tartu, Estonia }\end{array}$ \\
\hline $60-69$ & 235 & 7.0 & 0.0853 & $\begin{array}{l}\text { Helsinki, Finland } \\
\text { Khanti-Mansiysk, } \\
\text { Russia } \\
\text { Trondheim, Norway }\end{array}$ \\
\hline $70-79$ & 1 & 0.0 & 0.0195 & $\begin{array}{l}\text { Hammerfest, } \\
\text { Norway }\end{array}$ \\
\hline Hemisphere & $\mathrm{N}$ & $\%$ & & \\
\hline Northern Hemisphere & 2834 & 84.2 & 0.3917 & \\
\hline Southern Hemisphere & 531 & 15.8 & 0.5278 & \\
\hline
\end{tabular}

abuse, living in a country with a state-sponsored or favored religion, and birth cohort. The estimated coefficients suggested that a 0.1 percent increase in the ratio of mean winter to summer insolation will decrease the odds of a suicide attempt by about $4.9 \%$. Comparing the largest ratio (near the equator) to the smallest ratio (near the north pole), there was a $49 \%$ decrease in the odds of a suicide attempt. Being male will decrease the odds of a suicide attempt by $47 \%$, and living in a country with a state-sponsored or favored religion will decrease the odds by $32 \%$. Having a history of alcohol or substance abuse will increase the odds of a suicide attempt by $66 \%$. Being in the youngest birth cohort will increase the odds of a suicide attempt by $116 \%$, and being in the middle birth cohort will increase the odds by $97 \%$.

The other solar insolation and socioeconomic values were not significant or the model results not as meaningful.

\section{Discussion}

In this global sample, $31 \%$ of the patients with bipolar I disorder have a history of suicide attempt, similar to prior research (Tondo et al., 2016; Vieta et al., 2018). The ratio of the mean winter solar insolation/ mean summer solar insolation was inversely associated with an increased risk of suicide attempts. Patients from locations with smaller differences between mean winter and summer insolation such as near the equator (high ratio) had fewer suicide attempts, while those from locations with larger differences between mean winter and summer insolation (small ratio) had more suicide attempts. In the general population, suicide is a major public health challenge in polar regions with very high rates in places such as Greenland, arctic areas of Canada and Russia, and Alaska (Alaska Epidemiology, 2013; Bjerregaard and Larsen, 2015; Lehti et al., 2009; Young et al., 2015), and higher than national suicide rates in southernmost Argentina and Chile (Bustamante et al., 2016; Lawrynowicz and Baker, 2005).

There are few studies of solar radiation and suicide rates in the general population, with all studies occurring within a single country. Increased solar radiation in spring and summer was associated with an increased suicide rate in South Korea (Jee et al., 2017), and increased solar radiation may precede suicidal acts in Germany and Greece (Müller et al., 2011; Papadopoulos et al., 2005). The cumulative low solar radiation during the long northern winter was associated with an increased risk of suicide in Finland (Ruuhela et al., 2009). Several additional lines of evidence suggest that solar insolation may be associated with suicide attempts.

\subsection{Fundamental importance of sunlight}

Sunlight has broad impacts on human physiology and behavior (Munch et al., 2017; Wirz-Justice, 2006). Humans have adapted to the $24 \mathrm{~h}$ light-dark cycles on Earth by developing a complex, hierarchical endogenous circadian system that is involved in virtually all physiological processes, tissue homeostasis and cellular functions (AMA, 2012; Richards and Gumz, 2013; Rosenwasser and Turek, 2015). The circadian system includes a central pacemaker in the suprachiasmatic nucleus (SCN) of the hypothalamus, and extends to circadian clock genes throughout the brain and all peripheral tissues (Rosenwasser and Turek, 2015). Although the periodicity of the endogenous circadian system is

Table 3

Estimated parameters explaining a history of suicide attempts for patients with bipolar I disorder $(\mathrm{N}=3365)^{\mathrm{a}}$.

\begin{tabular}{|c|c|c|c|c|c|c|}
\hline \multirow[t]{2}{*}{ Parameters } & \multirow[t]{2}{*}{ Coefficient estimate } & \multirow[t]{2}{*}{ Standard error } & \multicolumn{2}{|c|}{$99 \%$ Confidence interval } & \multicolumn{2}{|c|}{ Coefficient significance } \\
\hline & & & Lower & Upper & Wald Chi-square & $\mathrm{P}$ \\
\hline Ratio mean winter insolation/mean summer insolation at onset location & -0.679 & 0.2061 & -1.210 & -0.149 & 10.869 & 0.001 \\
\hline State sponsored religion in onset country & -0.380 & 0.1409 & -0.743 & -0.018 & 7.291 & 0.007 \\
\hline Male & -0.635 & 0.0934 & -0.875 & -0.394 & 46.140 & $<0.001$ \\
\hline History of alcohol or substance abuse & 0.506 & 0.0682 & 0.331 & 0.682 & 55.152 & $<0.001$ \\
\hline $\mathrm{DOB} \geq 1960$ & 0.770 & 0.2324 & 0.171 & 1.369 & $10.980^{\mathrm{b}}$ & $0.001^{\mathrm{b}}$ \\
\hline DOB $\geq 1940$ and $\mathrm{DOB}<1960$ & 0.679 & 0.2103 & 0.138 & 1.221 & $10.440^{\mathrm{b}}$ & $0.001^{\mathrm{b}}$ \\
\hline
\end{tabular}

a Dependent variable: History of suicide attempts (yes/no). Model: intercept, ratio of mean winter insolation/mean summer insolation at onset location, state

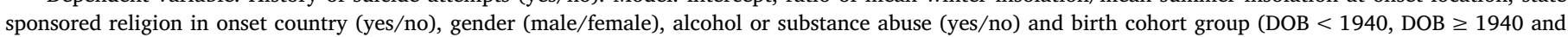
DOB $<1960$, DOB $\geq 1960$ ).

b Individual parameters Wald chi-square statistic and significance. The model effects Wald chi-square and significance for the cohort parameter was 11.266 and 0.004 respectively with 2 degrees of freedom. 
near $24 \mathrm{~h}$, daily entrainment is required to maintain alignment with the natural environment (AMA, 2012). Light is the primary signal that entrains the human circadian system to the environment, allowing for anticipation and adaptation to environmental and seasonal changes (AMA, 2012; Roenneberg and Merrow, 2016; Silver and Lesauter, 2008). Entrainment involves a small subset of melanopsin-expressing inner retinal ganglion cells, not involved in image formation, that detect fluctuations in the intensity of environmental light and project to the brain including the SCN (Berson et al., 2002; Hatori and Panda, 2010). The melanopsin system is involved in many other non-image forming responses to light, including melatonin suppression, sleep regulation, the pupillary light response, and enhancing alertness (Benarroch, 2011; Berman et al., 2018; Ksendzovsky et al., 2017; Warthen and Provencio, 2012). Circadian health requires both external synchronization with the environment and internal synchronization of central and peripheral clocks (Roenneberg and Merrow, 2016; Rosenwasser and Turek, 2015).

\subsection{Seasonal variations in neurotransmitters}

There are seasonal variations in the neurotransmitters involved in mood regulation, and these changes may be triggered by sunlight (Christodoulou et al., 2012; Petridou et al., 2002). It is postulated that complex interactions involving genetic vulnerabilities, circadian signaling pathways and altered neurotransmitter homeostasis may modify the seasonal response in bipolar disorder, and that seasonal variations in neurotransmitter expression may trigger switches between mood states (Maruani et al., 2018; Young and Dulcis, 2015).

Many studies focus on serotonin. In studies primarily of healthy humans, serotonin turnover by the brain is lowest in winter (Lambert et al., 2002), serotonin metabolite levels in cerebrospinal fluid peak in spring (Brewerton et al., 2018; Luykx et al., 2012), and brain serotonin transporter binding density, which increases with lower synaptic levels, is higher in fall and winter (Praschak-Rieder et al., 2008). There is also diurnal variation in brain serotonin receptors and transporters levels associated with the hours of daylight (Matheson et al., 2015). Serotonin is the neurotransmitter most frequently linked with aggressive and suicidal behavior (Coccaro et al., 2015; Manchia et al., 2017; van Heeringen and Mann, 2014). One hypothesis is that serotonergic medications may enhance the association between sunlight and suicide in the short term (Makris et al., 2016). Studies of dopamine synthesis and turnover report inconsistent seasonal changes with some finding higher dopamine in summer (Aumann et al., 2016; Tsai et al., 2011) and others in winter (Brewerton et al., 2018; Eisenberg et al., 2010). There are also seasonal changes in the neurotransmitter modulator BDNF with serum levels increasing in spring and decreasing in winter (Molendijk et al., 2012).

Vitamin D is a neurosteroid that modulates multiple functions in the developing and adult brain (Cui et al., 2017; Groves et al., 2014). Seasonality is also found in vitamin D levels globally, with lowest levels in winter in most age groups in most areas (Mithal et al., 2009). Vitamin D deficiency may be associated with mental disturbances including bipolar disorder and depression (Boerman et al., 2016; Lerner et al., 2018; Parker et al., 2017; Spedding, 2014), and an increased risk of suicide (Grudet et al., 2014; Umhau et al., 2013).

\subsection{Consistency of other variables with prior research}

The other variables associated with a history of suicide attempts in this analysis are consistent with prior research. A strong association between alcohol and substance abuse and a history of suicide attempts was found in patients with bipolar disorder (Carrà et al., 2014; Østergaard et al., 2017; Tidemalm et al., 2014), and in international studies of the general population (Borges and Loera, 2010; Norström and Rossow, 2016; Pompili et al., 2010) including in low- and middleincome countries (Breet et al., 2018). This strong association is of considerable concern given the high prevalence of alcohol and substance abuse in patients with bipolar disorder (Hunt et al., 2016). More frequent suicide attempts by females than males were also noted in studies of bipolar disorder and of the general population (Borges et al., 2010; Schaffer et al., 2015; Tondo et al., 2016).

The finding that living in a country with a state-sponsored or preferred religion decreases the risk of suicide attempts also concurs with international research. Review articles including all major world religions have reported that the prevalent religion has a strong cultural impact, that suicide rates are lower in religious countries, and that religion may be protective against suicide and suicide attempts (Bertolote and Fleischmann, 2002; Lawrence et al., 2016; Norko et al., 2017; Stack and Kposowa, 2011; Wu et al., 2015). The finding of increasing risk of suicide attempts in younger birth cohorts is consistent with well established birth cohort effects of increasing suicide rates in younger cohorts in many countries (Granizo et al., 1996; Gunnell et al., 2003; Kwon et al., 2009; Murphy and Wetzel, 1980; Odagiri et al., 2011; Phillips, 2014). Broad societal changes are thought to contribute increasing vulnerability to suicide in younger birth cohorts including a loss of social integration and assimilation, and rapid shifts in the norms and customs that regulate behavior (Griffith and Bryan, 2016; Phillips, 2014; Stockard and O'Brien, 2002).

\subsection{Limitations}

There are limitations to this post-hoc exploratory study. The data analysis plan was not pre-specified, and the analyses cannot demonstrate causality or predict individual behavior. The database was not designed to collect data about suicide. There was no information on individual parameters associated with suicide attempts including marital status, education, income, employment, childhood trauma, family history of suicide, psychiatric and medical comorbidities, temperament, and individual religiosity (Borges et al., 2010; Hansson et al., 2018; Isometsä, 2014; Schaffer et al., 2015; Tondo et al., 2018). There was no data on patients receiving long-term lithium treatment, which may lower suicide risk (Baldessarini et al., 2006), or other therapies that target or modify the circadian system (Bellivier et al., 2015). There was no data on the timing of the suicide attempts, the patient age when attempts were made, and the relation of attempts to the phase of illness (Pallaskorpi et al., 2017). There was no individual data on Sun or lighting exposure (Bauer et al., 2018). Although based on DSM-IV criteria, data gathering was not standardized across the collection sites including both the definition of suicide attempt and assessment method. Additionally, both the increase in diagnosis (Blader and Carlson, 2007) and excess mortality of bipolar disorder (Osby, 2001), may bias findings relating to birth cohort effects.

Shifting data from the southern hemisphere by 6 months may discount cultural impacts of seasonality. Social variables may also be seasonal, such as the start of school sessions, but were not available (Matsubayashi et al., 2016). This analysis also did not investigate life habits, now common in the 21 st century, which may enable or directly cause circadian disruption including working shifts and irregular hours (Lunn et al., 2017; McMenamin, 2007) and exposure to light-emitting diodes (LED). White LEDs, used for lighting and to backlight digital devices, have a dominant spectral wavelength in the blue light range near the peak sensitivity for the melanopsin system (Bauer et al., 2018). Other environmental factors were not considered (Bakian et al., 2015; Berk et al., 2006; Fountoulakis et al., 2016).

\subsection{Solar insolation limitations}

Two important issues related to solar insolation cannot be analyzed with this database. First, with winters lasting longer than 3 months near the poles, the association of continuous low solar insolation with suicidal behaviors needs investigation. Second, the 22-year average solar insolation values capture the dramatic variation in solar insolation 
experienced at locations around the globe but do not highlight the regional variance in insolation that has occurred over decadal timeframes (Wild et al., 2005). In many parts of the world, there was declining insolation or solar dimming between the 1950s and 1980s, followed by increasing insolation or solar brightening since the 1980s (Wild, 2012). Solar dimming and brightening are caused by changes in the transparency of the atmosphere, not directly by the Sun. Increasing clouds, aerosols and gases in the atmosphere often from air pollution are associated with solar dimming, while the opposite environmental controls are associated with brightening (Tollenaar et al., 2017; Wild, 2012). For example, in the post-2000 decade, strong solar brightening was noted in some areas of the US and Japan, with dimming in some areas of India and China (Hatzianastassiou et al., 2012; Tollenaar et al., 2017; Wild, 2009, 2012). Areas within a country may have opposite tendencies or may not be impacted, and the direction of future changes is unclear (Hatzianastassiou et al., 2012; Tollenaar et al., 2017; Wild, 2009, 2012). The potential relation between local insolation variability and suicidal behaviors should be investigated.

\section{Conclusion}

In conclusion, this exploratory analysis suggests that living in locations with large changes in solar insolation between winter and summer may be associated with increased suicide attempts in patients with bipolar disorder. Given the increased recognition of the importance of sunlight on human behavior and the frequent presence of circadian rhythm dysfunction in bipolar disorder, more knowledge of the relation of solar insolation to suicide attempts is needed.

\section{Conflicts of interest}

All authors declare that they have no conflict of interest.

\section{Contributors}

All authors contributed to and approved the final manuscript. Authors $\mathrm{MB}$ and TG designed the study and provided a draft manuscript. Authors MA, OAA, EA, RA, YA, CB, RB, BTB, CBP, FB, RHB, MB, YB, SB, HBO, TDB, JC, EYWC, MDZ, SD, MD, BE, AF, KNF, MAF, AGP, JFG, PG, HH, CH, ETI, SJ, FK, MK, SK, SK, BK, TLK, RK, MK, BL, ML, ERL, UL, RWL, CLJ, GM, MM, WM, MMC, IM, FMU, MYM, SM, GM, EM, AAM, RM, SVM, FN, RKN, FGN, REN, CO, AO, YO, HOS, UO, YPR, MP, MP, FDRP, DQ, RR, NR, MSR, AR, PR, JKR, KS, BSR, AMS, ES, CS, DJS, SS, MS, AHS, KS, HT, YT, LT, CT, AEV, EV, JV, EV, BV, MYN, MZ and YZ were involved with data collection. Author TG provided data analysis. Authors PWS and PCW were involved in the initial review.

\section{Role of the funding source}

The funding sources had no involvement in the study design, data collection, analysis, interpretation, report writing or the decision to submit for publication.

\section{Acknowledgement}

Michael Berk is supported by an NHMRC Senior Principal Research Fellowship (APP1059660 and APP1156072). Ole A Andreassen, Thomas D Bjella and Ingrid Melle are supported by Research Council of Norway (223273) and KG Jebsen Stiftelsen. Ravi Nadella has received funding from the Accelerator program for Discovery in Brain disorders using Stem cells (ADBS), jointly funded by the Department of Biotechnology, Government of India, and the Pratiksha trust. Biju Viswanath has received funding by Department of Science and Technology INSPIRE scheme, Government of India. Mikael Landén was supported by grants from the Swedish Research Council (K2014-62X14647-12-51 and K2010-61P-21568-01-4), the Swedish Foundation for
Strategic Research (KF10-0039), and the Swedish Federal Government under the LUA/ALF agreement (ALF 20130032, ALFGBG-142041).

We thank Haydeh Olofsson for valuable data management support.

\section{References}

Abreu, T., Bragança, M., 2015. The bipolarity of light and dark: a review on Bipolar Disorder and circadian cycles. J. Affect. Disord. 185, 219-229.

Aguglia, A., Borsotti, A., Cuniberti, F., Serafini, G., Amore, M., Maina, G., 2017. The influence of sunlight exposure on hospitalization in emergency psychiatry. Chronobiol. Int. 34, 1413-1422.

Alaska Epidemiology Bulletin, 2013. Risk Factors for Suicide at the Community Level Alaska, 2003-2011. http://www.epi.alaska.gov/bulletins/docs/rr2013_01.pdf\# storylink = relast, Accessed date: 6 September 2018.

Alloy, L.B., Ng, T.H., Titone, M.K., Boland, E.M., 2017. Circadian rhythm dysregulation in bipolar spectrum disorders. Curr. Psychiatr. Rep. 19, 21.

AMA (American Medical Association), 2012. Light pollution: adverse health effects of nighttime lighting. In: Proceedings of the American Medical Association House of Delegates, 161st Annual Meeting, Chicago, IL, pp. 265-279. https://www.ama-assn. $\mathrm{org} /$ sites/default/files/media-browser/public/hod/a12-csaph-reports_0.pdf, Accessed date: 6 September 2018.

Aumann, T.D., Raabus, M., Tomas, D., Prijanto, A., Churilov, L., Spitzer, N.C., et al., 2016. Differences in number of midbrain dopamine neurons associated with summer and winter photoperiods in humans. PLoS One 11 e0158847.

Bakian, A.V., Huber, R.S., Coon, H., Gray, D., Wilson, P., McMahon, W.M., et al., 2015. Acute air pollution exposure and risk of suicide completion. Am. J. Epidemiol. 181, 295-303.

Baldessarini, R.J., Tondo, L., Davis, P., Pompili, M., Goodwin, F.K., Hennen, J., 2006. Decreased risk of suicides and attempts during long-term lithium treatment: a metaanalytic review. Bipolar Disord. 8, 625-639.

Barker, A., Hawton, K., Fagg, J., Jennison, C., 1994. Seasonal and weather factors in parasuicide. Br. J. Psychiatry 165, 375-380.

Bauer, M., Glenn, T., Alda, M., Andreassen, O.A., Ardau, R., Bellivier, F., et al., 2012 Impact of sunlight on the age of onset of bipolar disorder. Bipolar Disord. 14, 654-663.

Bauer, M., Glenn, T., Alda, M., Andreassen, O.A., Angelopoulos, E., Ardau, R., et al., 2014 Relationship between sunlight and the age of onset of bipolar disorder: an international multisite study. J. Affect. Disord. 167, 104-111.

Bauer, M., Glenn, T., Alda, M., Andreassen, O.A., Angelopoulos, E., Ardau, R., et al., 2015 Influence of birth cohort on age of onset cluster analysis in bipolar I disorder. Eur. Psychiatry 30, 99-105.

Bauer, M., Glenn, T., Alda, M., Aleksandrovich, M.A., Andreassen, O.A., Angelopoulos, E., et al., 2017. Solar insolation in springtime influences age of onset of bipolar I disorder. Acta Psychiatr. Scand. 136, 571-582.

Bauer, M., Glenn, T., Monteith, S., Gottlieb, J.F., Ritter, P.S., Geddes, J., et al., 2018. The potential influence of LED lighting on mental illness. World J. Biol. Psychiatr. 19, 59-73.

Bechtel, W., 2015. Circadian rhythms and mood disorders: are the phenomena and mechanisms causally related? Front. Psychiatry 6, 118.

Bellivier, F., Geoffroy, P.A., Etain, B., Scott, J., 2015. Sleep- and circadian rhythm-associated pathways as therapeutic targets in bipolar disorder. Expert Opin. Ther. Targets 19, 747-763.

Benarroch, E.E., 2011. The melanopsin system: phototransduction, projections, functions, and clinical implications. Neurology 76, 1422-1427.

Berk, M., Dodd, S., Henry, M., 2006. Do ambient electromagnetic fields affect behaviour? A demonstration of the relationship between geomagnetic storm activity and suicide. Bioelectromagnetics 27, 151-155.

Berman, G., Muttuvelu, D., Berman, D., Larsen, J.I., Licht, R.W., Ledolter, J., Kardon, R.H., 2018. Decreased retinal sensitivity in depressive disorder: a controlled study. Acta Psychiatr. Scand. 137, 231-240.

Berson, D.M., Dunn, F.A., Takao, M., 2002. Phototransduction by retinal ganglion cells that set the circadian clock. Science 295, 1070-1073.

Bertolote, J.M., Fleischmann, A., 2002. A global perspective in the epidemiology of suicide. Suicidologi 7 (2), 6-8.

Bjerregaard, P., Larsen, C.V., 2015. Time trend by region of suicides and suicidal thoughts among Greenland Inuit. Int. J. Circumpolar Health 74, 26053.

Blader, J.C., Carlson, G.A., 2007. Increased rates of bipolar disorder diagnoses among U.S child, adolescent, and adult inpatients, 1996-2004. Biol. Psychiatry 62, 107-114.

Boerman, R., Cohen, D., Schulte, P.F., Nugter, A., 2016. Prevalence of Vitamin D deficiency in adult outpatients with bipolar disorder or schizophrenia. J. Clin. Psychopharmacol. 36, 588-592.

Borges, G., Loera, C.R., 2010. Alcohol and drug use in suicidal behaviour. Curr. Opin. Psychiatr. 23, 195-204.

Borges, G., Nock, M.K., Haro Abad, J.M., Hwang, I., Sampson, N.A., Alonso, J., et al., 2010. Twelve-month prevalence of and risk factors for suicide attempts in the world health organization world mental health surveys. J. Clin. Psychiatry 71, 1617-1628.

Breet, E., Goldstone, D., Bantjes, J., 2018. Substance use and suicidal ideation and behaviour in low- and middle-income countries: a systematic review. BMC Public Health 18, 549.

Brewerton, T.D., Putnam, K.T., Lewine, R.R.J., Risch, S.C., 2018. Seasonality of cerebrospinal fluid monoamine metabolite concentrations and their associations with meteorological variables in humans. J. Psychiatr. Res. 99, 76-82.

Bustamante, F., Ramirez, V., Urquidi, C., Bustos, V., Yaseen, Z., Galynker, I., 2016. Trends and most frequent methods of suicide in Chile between 2001 and 2010. Crisis 37 
$21-30$.

Carr, O., Saunders, K.E.A., Tsanas, A., Bilderbeck, A.C., Palmius, N., Geddes, J.R., et al., 2018. Variability in phase and amplitude of diurnal rhythms is related to variation of mood in bipolar and borderline personality disorder. Sci. Rep. 8, 16.

Carrà, G., Bartoli, F., Crocamo, C., Brady, K.T., Clerici, M., 2014. Attempted suicide in people with co-occurring bipolar and substance use disorders: systematic review and meta-analysis. J. Affect. Disord. 167, 125-135.

Christodoulou, C., Douzenis, A., Papadopoulos, F.C., Papadopoulou, A., Bouras, G., Gournellis, R., et al., 2012. Suicide and seasonality. Acta Psychiatr. Scand. 125, 127-146.

CIA, 2016. World Factbook. Washington, DC. Available at: https://www.cia.gov/ library/publications/the-world-factbook/, Accessed date: 6 September 2018 .

Coccaro, E.F., Fanning, J.R., Phan, K.L., Lee, R., 2015. Serotonin and impulsive aggression. CNS Spectr. 20, 295-302.

Coimbra, D.G., Pereira, E., Silva, A.C., de Sousa-Rodrigues, C.F., Barbosa, F.T., de Siqueira Figueredo, D., et al., 2016. Do suicide attempts occur more frequently in the spring too? A systematic review and rhythmic analysis. J. Affect. Disord. 196, 125-137.

Cui, X., Gooch, H., Petty, A., McGrath, J.J., Eyles, D., 2017. Vitamin D and the brain: genomic and non-genomic actions. Mol. Cell. Endocrinol. 453, 131-143.

Dixon, P.G., Kalkstein, A.J., 2018. Where are weather-suicide associations valid? An examination of nine US counties with varying seasonality. Int. J. Biometeorol. 62, 685-697.

Eisenberg, D.P., Kohn, P.D., Baller, E.B., Bronstein, J.A., Masdeu, J.C., Berman, K.F., 2010. Seasonal effects on human striatal presynaptic dopamine synthesis. J. Neurosci. 30, 14691-14694.

Fountoulakis, K.N., Chatzikosta, I., Pastiadis, K., Zanis, P., Kawohl, W., Kerkhof, A.J., et al., 2016. Relationship of suicide rates with climate and economic variables in Europe during 2000-2012. Ann. Gen. Psychiatr. 15, 19.

Galvão, P.V.M., Silva, H.R.S.E., Silva, C.M.F.P.D., 2018. Temporal distribution of suicide mortality: a systematic review. J. Affect. Disord. 228, 132-142.

Geoffroy, P.A., Bellivier, F., Scott, J., Etain, B., 2014. Seasonality and bipolar disorder: a systematic review, from admission rates to seasonality of symptoms. J. Affect. Disord. 168, 210-223.

Geoffroy, P.A., Lajnef, M., Bellivier, F., Jamain, S., Gard, S., Kahn, J.P., et al., 2015. Genetic association study of circadian genes with seasonal pattern in bipolar dis orders. Sci. Rep. 5, 10232.

Granizo, J.J., Guallar, E., Rodríguez-Artalejo, F., 1996. Age-period-cohort analysis of suicide mortality rates in Spain, 1959-1991. Int. J. Epidemiol. 25, 814-820.

Griffith, J., Bryan, C.J., 2016. Suicides in the US military: birth cohort vulnerability and the all-volunteer force. Armed Forces Soc. 42, 483-500.

Groves, N.J., McGrath, J.J., Burne, T.H., 2014. Vitamin D as a neurosteroid affecting the developing and adult brain. Annu. Rev. Nutr. 34, 117-141.

Grudet, C., Malm, J., Westrin, A., Brundin, L., 2014. Suicidal patients are deficient in vitamin $\mathrm{D}$, associated with a pro-inflammatory status in the blood. Psychoneuroendocrinology 50, 210-219.

Gunnell, D., Middleton, N., Whitley, E., Dorling, D., Frankel, S., 2003. Influence of cohort effects on patterns of suicide in England and Wales, 1950-1999. Br. J. Psychiatry 182, 164-170.

Hansson, C., Joas, E., Pålsson, E., Hawton, K., Runeson, B., Landén, M., 2018. Risk factors for suicide in bipolar disorder: a cohort study of 12850 patients. Acta Psychiatr. Scand. Aug 3https://doi.org/10.1111/acps.12946. ([Epub ahead of print]).

Harvey, A.G., 2008. Sleep and circadian rhythms in bipolar disorder: seeking synchrony, harmony, and regulation. Am. J. Psychiatry 165, 820-829.

Hatori, M., Panda, S., 2010. The emerging roles of melanopsin in behavioral adaptation to light. Trends Mol. Med. 16, 435-446.

Hatzianastassiou, N., Papadimas, C.D., Matsoukas, C., Pavlakis, K., Fotiadi, A., Wild, M., et al., 2012. Recent regional surface solar radiation dimming and brightening patterns: inter-hemispherical asymmetry and a dimming in the Southern Hemisphere. Atmos. Sci. Lett. 13, 43-48.

Hunt, G.E., Malhi, G.S., Cleary, M., Lai, H.M., Sitharthan, T., 2016. Prevalence of comorbid bipolar and substance use disorders in clinical settings, 1990-2015: systematic review and meta-analysis. J. Affect. Disord. 206, 331-349.

Isometsä, E., 2014. Suicidal behaviour in mood disorders-who, when, and why? Can. J. Psychiatr. 59, 120-130.

Jagannath, A., Peirson, S.N., Foster, R.G., 2013. Sleep and circadian rhythm disruption in neuropsychiatric illness. Curr. Opin. Neurobiol. 23, 888-894.

Jee, H.J., Cho, C.H., Lee, Y.J., Choi, N., An, H., Lee, H.J., 2017. Solar radiation increases suicide rate after adjusting for other climate factors in South Korea. Acta Psychiatr. Scand. 135, 219-227.

Jones, S.G., Benca, R.M., 2015. Circadian disruption in psychiatric disorders. Sleep Med. Clin. 10, 481-493.

Ketchesin, K.D., Becker-Krail, D., McClung, C.A., 2018. Mood-related central and peripheral clocks. 2018 Nov 6. Eur. J. Neurosci. https://doi.org/10.1111/ejn.14253. ([Epub ahead of print]).

Ksendzovsky, A., Pomeraniec, I.J., Zaghloul, K.A., Provencio, J.J., Provencio, I., 2017. Clinical implications of the melanopsin-based non-image-forming visual system. Neurology 88, 1282-1290.

Kwon, J.W., Chun, H., Cho, S.I., 2009. A closer look at the increase in suicide rates in South Korea from 1986-2005. BMC Public Health 9, 72

Lambert, G.W., Reid, C., Kaye, D.M., Jennings, G.L., Esler, M.D., 2002. Effect of sunlight and season on serotonin turnover in the brain. Lancet 360, 1840-1842.

Lawrence, R.E., Oquendo, M.A., Stanley, B., 2016. Religion and suicide risk: a systematic review. Arch. Suicide Res, 20, 1-21.

Lawrynowicz, A.E., Baker, T.D., 2005. Suicide and latitude in Argentina: durkheim upside-down. Am. J. Psychiatry 162, 1022.

Lehti, V., Niemelä, S., Hoven, C., Mandell, D., Sourander, A., 2009. Mental health, substance use and suicidal behaviour among young indigenous people in the Arctic: a systematic review. Soc. Sci. Med. 69, 1194-1203.

Lerner, P.P., Sharony, L., Miodownik, C., 2018. Association between mental disorders, cognitive disturbances and vitamin D serum level: current state. Clin. Nutr. ESPEN. 23, 89-102.

Logan, R.W., McClung, C.A., 2019. Rhythms of life: circadian disruption and brain disorders across the lifespan. Nat. Rev. Neurosci. 20, 49-65.

Lunn, R.M., Blask, D.E., Coogan, A.N., Figueiro, M.G., Gorman, M.R., Hall, J.E., et al., 2017. Health consequences of electric lighting practices in the modern world: a report on the National Toxicology Program's workshop on shift work at night, artificia light at night, and circadian disruption. Sci. Total Environ. 607-608, 1073-1084.

Luykx, J.J., Bakker, S.C., Lentjes, E., Boks, M.P., van Geloven, N., Eijkemans, M.J., et al., 2012. Season of sampling and season of birth influence serotonin metabolite levels in human cerebrospinal fluid. PLoS One 7, e30497.

Makris, G.D., Reutfors, J., Larsson, R., Isacsson, G., Ösby, U., Ekbom, A., et al., 2016. Serotonergic medication enhances the association between suicide and sunshine. J. Affect. Disord. 189, 276-281.

Manchia, M., Carpiniello, B., Valtorta, F., Comai, S., 2017. Serotonin dysfunction, aggressive behavior, and mental illness: exploring the link using a dimensional approach. ACS Chem. Neurosci. 8, 961-972.

Matheson, G.J., Schain, M., Almeida, R., Lundberg, J., Cselényi, Z., Borg, J., et al., 2015. Diurnal and seasonal variation of the brain serotonin system in healthy male subjects. Neuroimage 112, 225-231.

Matsubayashi, T., Ueda, M., Yoshikawa, K., 2016. School and seasonality in youth suicide: evidence from Japan. J. Epidemiol. Community Health 70, 1122-1127.

Maruani, J., Anderson, G., Etain, B., Lejoyeux, M., Bellivier, F., Geoffroy, P.A., 2018. The neurobiology of adaptation to seasons: relevance and correlations in bipolar disorders. Chronobiol. Int. 1-19. https://doi.org/10.1080/07420528.2018.1487975. 2018 Jun 25.

McCarthy, M.J., 2018. Missing a beat: assessment of circadian rhythm abnormalities in bipolar disorder in the genomic era. Psychiatr. Genet. https://doi.org/10.1097/YPG. 0000000000000215. ([Epub ahead of print]).

McCarthy, M.J., Welsh, D.K., 2012. Cellular circadian clocks in mood disorders. J. Biol. Rhythms. 27, 339-352.

McClung, C.A., 2007. Circadian genes, rhythms and the biology of mood disorders. Pharmacol. Ther. 114, 222-232.

McMenamin, T.M., 2007. A time to work: recent trends in shift work and flexible schedules. US Bureau of Labor Statistics Monthly Labor Review 130, 3.

Melo, M.C.A., Abreu, R.L.C., Linhares Neto, V.B., de Bruin, P.F.C., de Bruin, V.M.S., 2017. Chronotype and circadian rhythm in bipolar disorder: a systematic review. Sleep Med. Rev. 34, 46-58.

Mithal, A., Wahl, D.A., Bonjour, J.P., Burckhardt, P., Dawson-Hughes, B., Eisman, J.A., et al., 2009. Global vitamin D status and determinants of hypovitaminosis. D. Osteoporos. Int. 20, 1807-1820.

Molendijk, M.L., Haffmans, J.P., Bus, B.A., Spinhoven, P., Penninx, B.W., Prickaerts, J., et al., 2012. Serum BDNF concentrations show strong seasonal variation and correlations with the amount of ambient sunlight. PLoS One 7, e48046.

Müller, H., Biermann, T., Renk, S., Reulbach, U., Ströbel, A., Kornhuber, J., et al., 2011. Higher environmental temperature and global radiation are correlated with increasing suicidality-a localized data analysis. Chronobiol. Int. 28, 949-957.

Munch, A.E., Brondsted, S.A., Brown, A., Gjedde, T., Kantermann, K., Martiny, D., et al., 2017. The effect of light on humans. In: Changing Perspectives on Daylight: Science, Technology, and Culture. Science/AAAS, Washington, DC, 2017, pp. 16-23.

Murphy, G.E., Wetzel, R.D., 1980. Suicide risk by birth cohort in the United States, 1949 to 1974. Arch. Gen. Psychiatr. 37, 519-523.

Ng, T.H., Chung, K.F., Ho, F.Y., Yeung, W.F., Yung, K.P., Lam, T.H., 2015. Sleep-wake disturbance in interepisode bipolar disorder and high-risk individuals: a systematic review and meta-analysis. Sleep Med. Rev. 20, 46-58.

Norko, M.A., Freeman, D., Phillips, J., Hunter, W., Lewis, R., Viswanathan, R., 2017. Can religion protect against suicide? J. Nerv. Ment. Dis. 205, 9-14.

Norström, T., Rossow, I., 2016. Alcohol consumption as a risk factor for suicidal behavior: a systematic review of associations at the individual and at the population level. Arch. Suicide Res. 20, 489-506.

Novick, D.M., Swartz, H.A., Frank, E., 2010. Suicide attempts in bipolar I and bipolar II disorder: a review and meta-analysis of the evidence. Bipolar Disord. 12, 1-9.

Odagiri, Y., Uchida, H., Nakano, M., 2011. Gender differences in age, period, and birthcohort effects on the suicide mortality rate in Japan, 1985-2006. Asia Pac. J. Public Health 23, 581-587.

Oliveira, T., Marinho, V., Carvalho, V., Magalhães, F., Rocha, K., Ayres, C., et al., 2018 Genetic polymorphisms associated with circadian rhythm dysregulation provide new perspectives on bipolar disorder. Bipolar Disord. 20, 515-522.

Osby, U., Brandt, L., Correia, N., Ekbom, A., Sparén, P., 2001. Excess mortality in bipolar and unipolar disorder in Sweden. Arch. Gen. Psychiatr. 58, 844-850.

$\emptyset$ stergaard, M.L.D., Nordentoft, M., Hjorthøj, C., 2017. Associations between substance use disorders and suicide or suicide attempts in people with mental illness: a Danish nation-wide, prospective, register-based study of patients diagnosed with schizophrenia, bipolar disorder, unipolar depression or personality disorder. Addiction 112, $1250-1259$.

Pallaskorpi, S., Suominen, K., Ketokivi, M., Valtonen, H., Arvilommi, P., Mantere, O., et al., 2017. Incidence and predictors of suicide attempts in bipolar I and II disorders: a 5-year follow-up study. Bipolar Disord. 19, 13-22.

Pan, W., 2001. Akaike's information criterion in generalized estimating equations. Biometrics 57, 120-125.

Papadopoulos, F.C., Frangakis, C.E., Skalkidou, A., Petridou, E., Stevens, R.G., Trichopoulos, D., 2005. Exploring lag and duration effect of sunshine in triggering suicide. J. Affect. Disord. 88, 287-297. 
Parker, G.B., Brotchie, H., Graham, R.K., 2017. Vitamin D and depression. J. Affect. Disord. 208, 56-61.

Petridou, E., Papadopoulos, F.C., Frangakis, C.E., Skalkidou, A., Trichopoulos, D., 2002. A role of sunshine in the triggering of suicide. Epidemiology 13, 106-109.

Pew Research Center, Oct. 3, 2017. Many Countries Favor Specific Religions, Officially or Unofficially. http://www.pewforum.org/2017/10/03/many-countries-favorspecific-religions-officially-or-unofficially/, Accessed date: 6 September 2018.

Phillips, J.A., 2014. A changing epidemiology of suicide? The influence of birth cohorts on suicide rates in the United States. Soc. Sci. Med. 114, 151-160.

Pompili, M., Serafini, G., Innamorati, M., Dominici, G., Ferracuti, S., Kotzalidis, G.D., et al., 2010. Suicidal behavior and alcohol abuse. Int. J. Environ. Res. Public Health 7, 1392-1431.

Postolache, T.T., Mortensen, P.B., Tonelli, L.H., Jiao, X., Frangakis, C., Soriano, J.J., et al., 2010. Seasonal spring peaks of suicide in victims with and without prior history of hospitalization for mood disorders. J. Affect. Disord. 121, 88-93.

Praschak-Rieder, N., Willeit, M., Wilson, A.A., Houle, S., Meyer, J.H., 2008. Seasonal variation in human brain serotonin transporter binding. Arch. Gen. Psychiatr. 65, 1072-1078.

Reutfors, J., Osby, U., Ekbom, A., Nordström, P., Jokinen, J., Papadopoulos, F.C., 2009. Seasonality of suicide in Sweden: relationship with psychiatric disorder. J. Affect. Disord. 119, 59-65.

Richards, J., Gumz, M.L., 2013. Mechanism of the circadian clock in physiology. Am. J. Physiol. Regul. Integr. Comp. Physiol. 304, R1053-R1064.

Rocchi, M.B., Sisti, D., Miotto, P., Preti, A., 2007. Seasonality of suicide: relationship with the reason for suicide. Neuropsychobiology 56, 86-92.

Roenneberg, T., Merrow, M., 2016. The circadian clock and human health. Curr. Biol. 26, R432-R443.

Rosenwasser, A.M., Turek, F.W., 2015. Neurobiology of circadian rhythm regulation. Sleep Med. Clin. 10, 403-412.

Ruuhela, R., Hiltunen, L., Venäläinen, A., Pirinen, P., Partonen, T., 2009. Climate impact on suicide rates in Finland from 1971 to 2003. Int. J. Biometeorol. 53, 167-175.

Schaffer, A., Isometsä, E.T., Azorin, J.M., Cassidy, F., Goldstein, T., Rihmer, Z., et al., 2015. A review of factors associated with greater likelihood of suicide attempts and suicide deaths in bipolar disorder: Part II of a report of the International Society for Bipolar Disorders Task Force on Suicide in Bipolar Disorder. Aust. N. Z. J. Psychiatr. 49, 1006-1020.

Silver, R., Lesauter, J., 2008. Circadian and homeostatic factors in arousal. Ann. N. Y. Acad. Sci. 1129, 263-274.

Soreca, I., 2014. Circadian rhythms and sleep in bipolar disorder: implications for pathophysiology and treatment. Curr. Opin. Psychiatr. 27, 467-471.

Spedding, S., 2014. Vitamin D and depression: a systematic review and meta-analysis comparing studies with and without biological flaws. Nutrients 6, 1501-1518.

Stack, S., Kposowa, A.J., 2011. Religion and suicide acceptability: a cross-national analysis. J. Sci. Study Relig. 50, 289-306.

Stackhouse Jr., P.W., Zhang, T., Westberg, D., Barnett, A.J., Bristow, T., Macpherson, B., et al., 2018. NASA POWER (Prediction of Worldwide Energy Resources). Release 8.01 (With GIS Applications) Methodology (Data Parameters, Sources, \& Validation). https://power.larc.nasa.gov, Accessed date: 6 September 2018.

Stockard, J., O'Brien, R.M., 2002. Cohort effects on suicide rates: international variations. Am. Sociol. Rev. 1, 854-872.

Takaesu, Y., 2018. Circadian rhythm in bipolar disorder: a review of the literature. Psychiatr. Clin. Neurosci. 72, 673-682.
Talih, F., Gebara, N.Y., Andary, F.S., Mondello, S., Kobeissy, F., Ferri, R., 2018. Delayed sleep phase syndrome and bipolar disorder: pathogenesis and available common biomarkers. Sleep Med. Rev. Feb 13https://doi.org/10.1016/j.smrv.2018.02.002. pii: S1087-0792(17)30225-3, ([Epub ahead of print]).

Tidemalm, D., Haglund, A., Karanti, A., Landén, M., Runeson, B., 2014. Attempted suicide in bipolar disorder: risk factors in a cohort of 6086 patients. PLoS One 9, e94097.

Tollenaar, M., Fridgen, J., Tyagi, P., Stackhouse Jr., P.W., Kumudini, S., 2017. The contribution of solar brightening to the US maize yield trend. Nat. Clim. Change 7, 275.

Tondo, L., Pompili, M., Forte, A., Baldessarini, R.J., 2016. Suicide attempts in bipolar disorders: comprehensive review of 101 reports. Acta Psychiatr. Scand. 133, 174-186.

Tondo, L., Vázquez, G.H., Sani, G., Pinna, M., Baldessarini, R.J., 2018. Association of suicidal risk with ratings of affective temperaments. J. Affect. Disord. 229, 322-327.

Tsai, H.Y., Chen, K.C., Yang, Y.K., Chen, P.S., Yeh, T.L., Chiu, N.T., et al., 2011. Sunshineexposure variation of human striatal dopamine $D(2) / D(3)$ receptor availability in healthy volunteers. Prog. Neuro-Psychopharmacol. Biol. Psychiatry 35, 107-110.

Umhau, J.C., George, D.T., Heaney, R.P., Lewis, M.D., Ursano, R.J., Heilig, M., et al., 2013. Low vitamin D status and suicide: a case-control study of active duty military service members. PLoS One 8, e51543.

van Heeringen, K., Mann, J.J., 2014. The neurobiology of suicide. Lancet Psychiatry 1, 63-72.

Vieta, E., Berk, M., Schulze, T.G., Carvalho, A.F., Suppes, T., Calabrese, J.R., et al., 2018. Bipolar disorders. Nat. Rev. Dis. Primers Mar 8, 4. https://doi.org/10.1038/nrdp. 2018.8. 18008.

Warthen, D.M., Provencio, I., 2012. The role of intrinsically photosensitive retinal ganglion cells in nonimage-forming responses to light. Eye Brain 4, 43-48.

WHO Mental Health Atlas, 2005. http://www.who.int/mental_health/evidence/ mhatlas05/en/, Accessed date: 6 September 2018.

WHO, 2018. 2018 Revision of World Urbanization Prospects. https://www.un.org/ development/desa/publications/2018-revision-of-world-urbanization-prospects. html, Accessed date: 23 January 2019.

Wild, M., Gilgen, H., Roesch, A., Ohmura, A., Long, C.N., Dutton, E.G., et al., 2005. From dimming to brightening: decadal changes in solar radiation at Earth's surface. Science $308,847-850$.

Wild, M., 2009. Global dimming and brightening: a review. J. Geophys. Res.: Atmosphere 114 (D10).

Wild, M., 2012. Enlightening global dimming and brightening. Bull. Am. Meteorol. Soc. 93, 27-37.

Wirz-Justice, A., 2006. Biological rhythm disturbances in mood disorders. Int. Clin. Psychopharmacol. 21 (Suppl. 1), S11-S15.

Woo, J.M., Okusaga, O., Postolache, T.T., 2012. Seasonality of suicidal behavior. Int. J. Environ. Res. Public Health 9, 531-547.

Wu, A., Wang, J.Y., Jia, C.X., 2015. Religion and completed suicide: a meta-analysis. PLoS One 10 e0131715.

Young, J.W., Dulcis, D., 2015. Investigating the mechanism(s) underlying switching between states in bipolar disorder. Eur. J. Pharmacol. 759, 151-162.

Young, T.K., Revich, B., Soininen, L., 2015. Suicide in circumpolar regions: an introduction and overview. Int. J. Circumpolar Health 74, 27349.

Zeger, S.L., Liang, K.Y., 1986. Longitudinal data analysis for discrete and continuous outcomes. Biometrics 42, 121e30. 